\title{
Study of auxiliary power system for electroplaters on the thermal engine basis
}

\author{
$R . V$. Vyatkin $^{1, *}, A . N$. Tikhomirov ${ }^{1}$, and D. A. Kolesnichenko ${ }^{1}$ \\ ${ }^{1}$ Nizhny Novgorod State Technical University n.a. R.E Alekseev, Nizhny Novgorod, Russia
}

\begin{abstract}
The article describes the design and testing of an auxiliary power system for a light commercial electric vehicle. In paper described research about load modes of auxiliary power system for maintaining performance of electric vehicle under low-charge conditions. The article describes the design work and the installation of the necessary components for the research. The authors describe the experiment of charging the traction battery from an auxiliary power source. The results of the study are presented, including an assessment of the effectiveness of using auxiliary power systems.
\end{abstract}

\section{Introduction}

In the very near future $(10 \ldots 15$ years $)$ it is planned to form a new market of vehicles around the world: automobiles with driver assistance systems - ADASsystems, automobiles with unmanned control functions and just automobiles on electric traction. The electric drive maximally corresponds to the modern trends of the "smart car", as well as significantly reduces toxic emissions from vehicles, which make up today about a quarter of all anthropogenic emissions [1-9].

Interest in electric cars is growing every year on the part of the consumer, who, on the one hand, does not want to fill up a car with expensive fuel and change engine oil every year, and on the other hand understands the proximity of the environmental disaster and is ready to take part in its removal [10-12]. However, it should not be forgotten that with the development of electric transport there are problems with the energy infrastructure, which is already working almost at the limit in large cities [13-20]. It will be necessary to increase the capacity of existing power plants, to accept the growth of carbon dioxide emissions at the electric power generation stage. The production of batteries, including extraction of raw materials, their processing, productions of chemically pure materials (cobalt, lithium, nickel) as well as logistics also require serious expenses.

Batteries are a major problem for the end user. Due to constant temperature changes, it is not possible to organize the ideal charging/discharging scheme for the battery - sooner or later it will fail and will need to be replaced. Moreover, due to insufficient development of science in this direction today, we have very modest runs on one battery charge. Also a big problem is the lack of necessary infrastructure, including charging stations. There is a risk that the battery capacity will not be sufficient to travel the required distance, and there will be no place to charge them.

Therefore, in Russian conditions (long distances between settlements, cold climate and poor infrastructure) it is not enough to have only electric drive on the vehicles. There is a need for an efficient auxiliary energy source that will ensure the mobility of the vehicle in various emergency situations.

The purpose of this work is to study the possibility of using an auxiliary power plant for the electric platform, which would ensure the performance in conditions of low battery charge, while maintaining the environmental friendliness of the electric platform. Based on the allmetal bus GAZelle NEXT prototype (figure 1), a gasoline generator designed to develop electric power was installed, thus charging the battery of the bus.

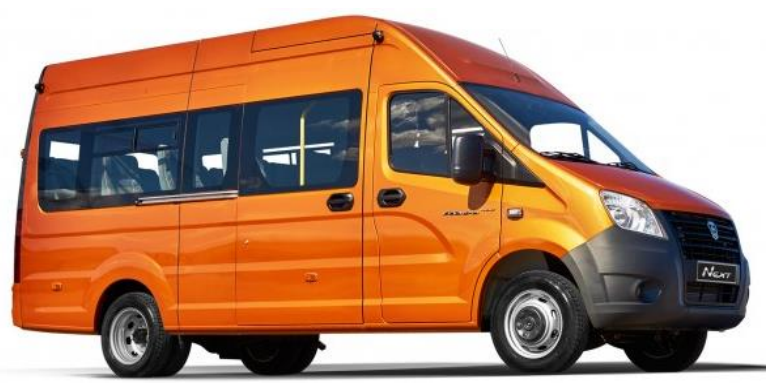

Fig. 1. All-metal bus GAZelle NEXT.

\section{Methods and materials}

As a power plant we used a gasoline generator FirmanRD-4910E (figure 2) with a capacity of $3.1 \mathrm{~kW}$. It was drawn in the Catia CAD system for the layout convenience on the 3D-model of the car GAZelle NEXT electric platform (figure 3).

\footnotetext{
*Corresponding author: solo151073@mail.ru
} 

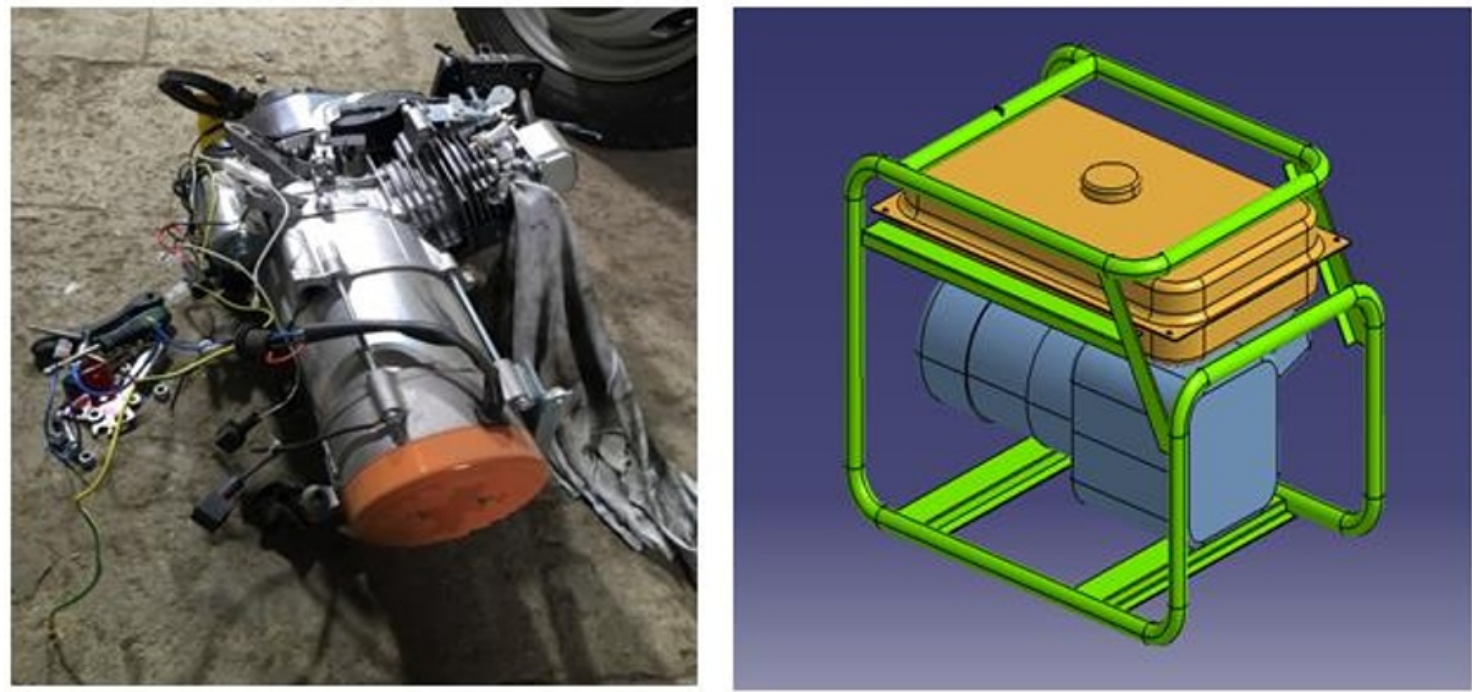

Fig. 2. Firman RD-4910E generator.

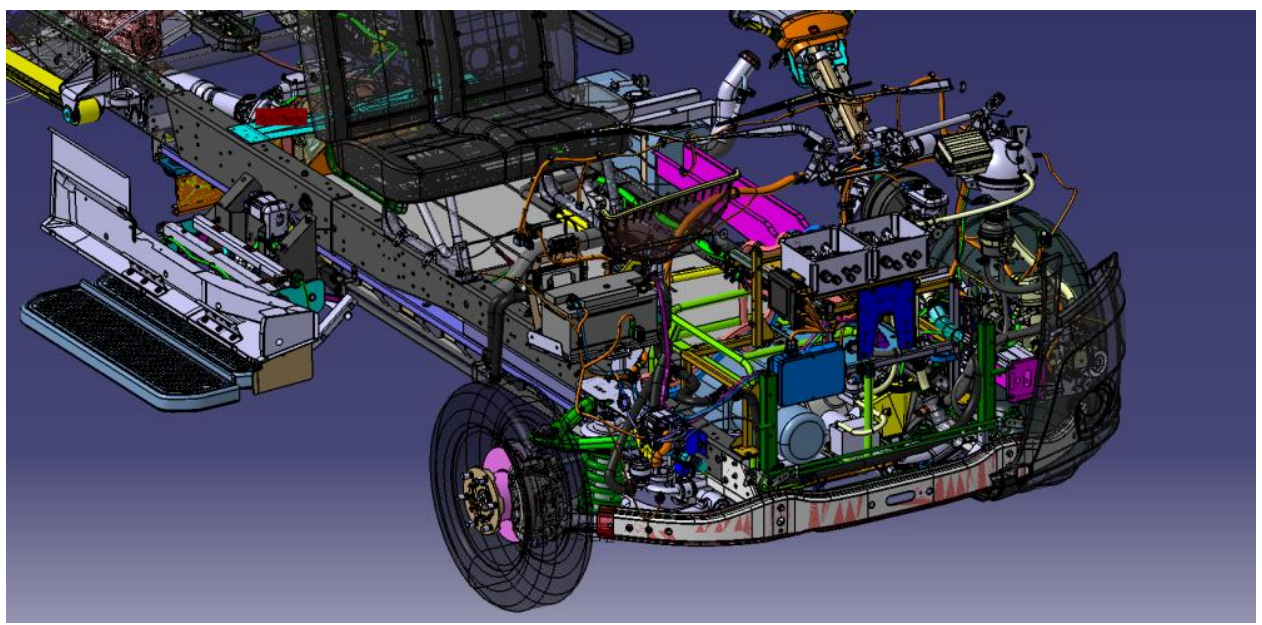

Fig. 3. Electric platform layout.

After the layout work and production of the generator mounting brackets, the generator was installed directly on the vehicle's electrical platform.

This layout allows unifying this solution and installing the generator on the entire line of GAZelle NEXT electric vehicles, including the low-floor bus.

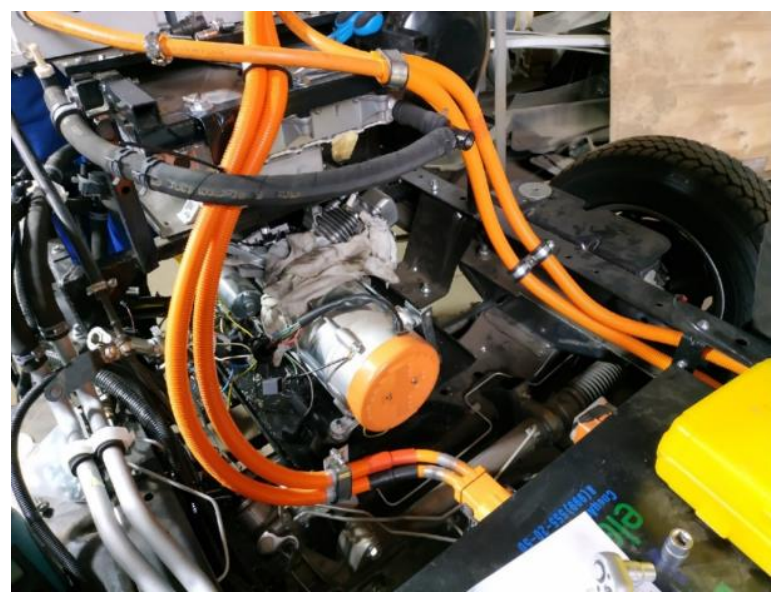

Fig. 4. Electric platform with gasoline generator.
After the layout design of the units, a series of tests was carried out as part of the electrical platform (figure 4). The tests were carried out in the laboratory of NGTU. The purpose of the test was to determine the real fuel efficiency of the auxiliary power plant on the charging the traction batteries mode of the electric platform according to a given algorithm.

In accordance with the methodical program, the electric platform was delivered to the test site with minimum energy reserves in the traction batteries. The battery management system indicated a charge rate of $17 \%$. The electric platform was securely fixed on the laboratory site with a parking brake. A Corrsys-Datron DFL3x fuel flow meter was mounted in the cargo area of the platform (figure 5). The fuel supply hoses from the tank to the engine were replaced by the standard ones from the flow meter set. To ensure that the required amount of fuel is provided an electric petrol pump with pressure regulator is installed in front of the flow meter maintaining the overpressure at the level of $30 \mathrm{kPa}$ for the carburetor smooth operation. The fuel pump was powered by a separate battery and was not included in the costs. 
Before starting the measurement, the electrical platform was kept for some time with the headlights on in order to discharge the batteries more efficiently. The auxiliary generator was started when the battery charge level of the BMS reached $15 \%$. At the same time, a frequency meter was activated to sum up the pulses of the fuel meter.

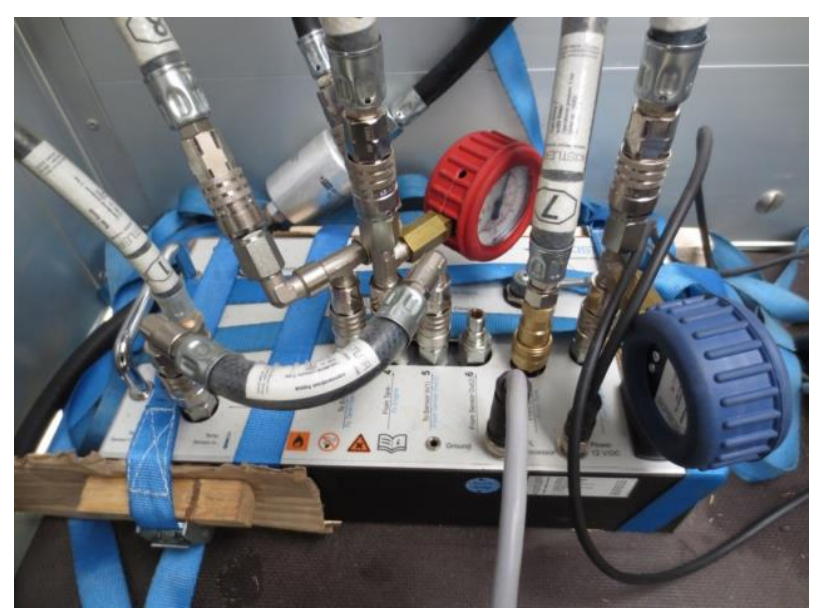

Fig. 5. Corrsys-Datron DFL3x fuel flow meter on GAZelle NEXT board with gasoline generator.

The charge calculation process began six minutes after the launch. During this time, the generator motor operated with a recoil current of not more than $5 \mathrm{~A}$ for uniform heating. Then the charging current was increased to $12 \mathrm{~A}$ and it remained so until the end of charging. Such an algorithm preliminarily tested on the bench tests, showed the efficiency of the installation and the ability to work in the zone of thermal engine maximum efficiency.

The charging process is shown in figure 6 .

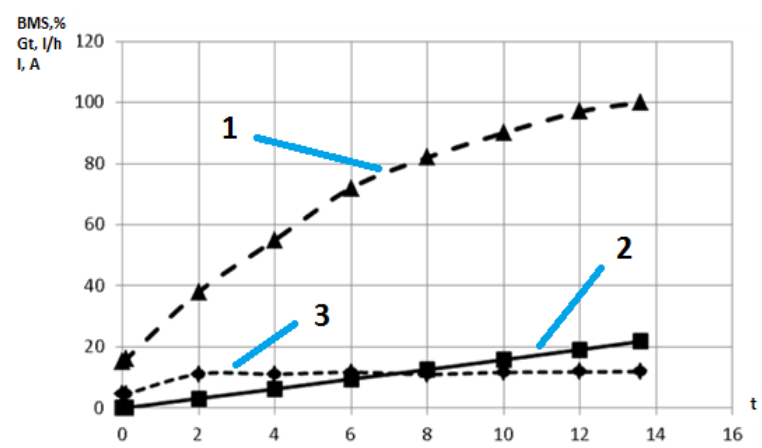

Fig. 6. Chart of the electric platform battery charging process with the help of the auxiliary power unit. Chart 1 - BMS, degree of charge of electric battery, $\%$; chart $2-\mathrm{Gt}$, fuel consumption, liter/ hour; chart 3 - charging current, A.

\section{Results and discussion}

The following conclusions can be drawn from this work. Firstly, the possibility of using an auxiliary power plant for the electrical platform is fully confirmed. The chosen scheme has advantages, among which there is a rational layout of a gasoline generator with the capacity of 3.1
$\mathrm{kW}$. It represents a unified solution for the entire line of GAZelle NEXT electric vehicles.

According to BMS measurements, the charge was carried out from the $15 \%$ to $100 \%$ charge degree in the $33.61 \mathrm{kWh}$ amount of electricity for the total time of 13.6 hours. The actual fuel consumption for the whole testing period was 21,793 liters, which is $16,02 \mathrm{~kg}$ at the measured density of gasoline equal to $\rho=735 \mathrm{~kg} / \mathrm{m} 3$. The conditional efficiency of the process (specific fuel consumption per charge) taking into account all internal losses of the generator and the charging system of the electric platform was $477 \mathrm{~g} / \mathrm{kWh}$, or, in other words, the efficiency providing for the calorific value of gasoline was $17.1 \%$.

Among the drawbacks is a small volume of the fuel tank, which had to be filled twice during the experiment. The second shortcoming is low efficiency of the onboard charging system in the low charging currents area. Designed for a charging power of about $15 \mathrm{~kW}$, the system at a power of about $3 \mathrm{~kW}$ has too low efficiency. To increase the system efficiency, it is necessary to enhance the charger performance coefficient in the area of low currents that are present when using auxiliary power units, or to create on board a separate charging system for the auxiliary thermal engine.

This research done with the financial support from Ministry of Science and Higher Education of the Russian Federation (the unique project identifier is RFMEFI57717X0268).

\section{References}

[1] Inside EVS [Electronic resource]: [official site]. Electronic data. Access mode: https://insideevs.com/smartcharge-new-york-get-paid-tocharge-your-

ev/?utm_campaign $=$ Newsletter\&utm_source $=$ hs_email\& utm_medium $=$ email\&utm_content $=5 \overline{4} 148646 \&$ hsenc $=$ p2ANqtz-92GLYzi_S9eThM4W6-

EualrLk0X3jh2d_9zuNhFNG0aLw5WFaPp1XYGZJHs

MIoCz9V1vb1WcTTy-kBUQcmY-

wgidg61Q\&_hsmi $=54170159$

[2] Driving News [Electronic resource]: [official site]. Electronic data. Access mode: http://driving.ca/autonews/news/motor-mouth-bigger-batteries-arent-theanswer-for-electric-cars

[3] O.B. Tikhomirova, A.N. Tikhomirov, Energy efficiency of electric transport, Transport systems 1, 714 (2018)

[4] Cyberleninka [Electronic resource]: [official site]. Electronic data. Access mode: https:/cyberleninka.ru/article/v/perspektivy-razvitiyaelektromobiley-i-avtomobiley-gibridov

[5] Cyberleninka [Electronic resource]: [official site]. Electronic data. Access mode: https://cyberleninka.ru/article/v/ekonomicheskiepredposylki-sozdaniya-avtomobiley-s-gibridnoy-silovoyustanovkoy-v-rossii

[6] Cyberleninka [Electronic resource]: [official site]. Electronic data. Access mode: 
https:/cyberleninka.ru/article/n/gibridnye-avtomobilireshenie-ekologicheskoy-problemy-avtomobilnogotransporta

[7] Japan Times [Electronic resource]: [official site]. Electronic data. Access mode: https://www.japantimes.co.jp/news/2016/03/16/business/ japan-eyes-40000-fuel-cell-cars-160-hydrogen-stationsby-2020/\#.Wkt1y9J18qx

[8] Green Car Reports [Electronic resource]: [official site]. - Electronic data. Access mode: https://www.greencarreports.com/news/1110239 energy -use-for-hydrogen-fuel-cell-vehicles-higher-thanelectrics-even-hybrids-analysis

[9] I. Akhmetova, A. Tyfetylov, A. Tamakchi, G. Khadiyllina, O. Derevianko, Z. Syed, Improving the competitiveness of automobile engineering enterprises by advancement the internal control over its indicators, International Journal of Civil Engineering and Technology, 9(13), 1865-1876 (2018)

[10] O.A. Filina, A.N. Tsvetkov, Evaluation of the operational life of direct current motors, IOP

Conference Series: Materials Science and Engineering, 489(1),012016 (2019)

[11] A.R. Safin, I.V. Ivshin, R.S. Misbakhov A.N. Tsvetkov, N.V. Denisova, Controlled rectifier simulation model development for reversible reciprocating electrical machine, International Journal of Pharmacy and Technology, 8(2), 14059-14068 (2016)

[12] E.I. Gracheva, O.V. Naumov, Operating mode influence on probability characteristics of electric devices, Journal of Engineering and Applied Sciences, 11(13), 2934-2938 (2016)

[13] CBC News [Electronic resource]: [official site]. Electronic data. Access mode: http://www.cbc.ca/news/canada/toronto/ontario-hopesrevised-condo-act-ev-friendly-1.4155747 (2018)

[14] A.A. Kalyutik, D.V. Grigorieva, A.V. Fedyukhin, O.V. Derevianko, I.G. Akhmetova, Reduction of the technological minimum by bypass method with environmental impact estimation on the example of energy blocks with T-100 and T-250/300-240 turbines, IOP Conference Series: Earth and Environmental Science, 288(1),012094 (2019)

[15] E. Sukhareva, A. Fedyukhin, O. Derevianko, M. Egorov, L. Mukhametova, I. Akhmetova, Optimization of combined heat and power plant operating mode by means of underutilized equipment mothball, IOP Conference Series: Earth and Environmental Science, 288(1),012122 (2019).

[16] V.I. Sitas, A.V. Fedyukhin, I.G. Akhmetova, A. Mitrofanov, S.O. Makoev, A. Asadpoori, A.A. Sinitsyn, E.A. Kikot, Assessment of technical and economic efficiency indicators of cogeneration in modern market conditions, International Journal of Civil Engineering and Technology, 10(2), 2106-2117 (2019)

[17] N.D. Agafonova, M.Y. Egorov, V.V. Sergeev, M.A. Gotovskii, P.A. Kruglikov, M.E. Lebedev, A.V. Sudakov, E.D. Fedorovich, B.S. Fokin, Heat-and-Mass Transfer Intensification in Saturated-Steam Generators in NPP with VVER as a Means for Increasing Efficiency and Reliability, Atomic Energy, 123(3), 154-158 (2018)
[18] I. Sultanguzin, A. Fedyukhin, V. Karasevich, A. Chernykh, Implementation of compressed air energy storages (CAES) for increasing efficiency of natural gas usage for power generation, International Gas Research Conference Proceedings, 2, 1193-1198 (2017)

[19] L.V. Plotnikova, L.A. Kashipova, R.A. Ishmuratov, Modeling of heat and power system optimal structure using software, Journal of Engineering and Applied Sciences, 11(14), 3028-3034 (2016)

[20] Y.N. Zvonareva, Y.V. Vankov, Energy saving in systems of heat supply of the large municipal associations powered from several sources of heat, Bulletin of the Tomsk Polytechnic University, Geo Assets Engineering, 326(11), 75-82 (2015) 